Claremont Colleges

Scholarship@Claremont

WM Keck Science Faculty Papers

W.M. Keck Science Department

$1-1-2010$

\title{
A Unique Population of Cave Bears (Carnivora: Ursidae) from the Middle Pleistocene of Kents Cavern, England, Based on Dental Morphometrics
}

Donald A. McFarlane

Claremont McKenna College; Pitzer College; Scripps College

Martin Sabol

Comenius University in Bratislava

Joyce Lundberg

Carleton University

\section{Recommended Citation}

McFarlane, D. A., Lundberg, J. and Sabol, M. (2010). "A unique population of cave bears (Carnivora: Ursidae) from the Middle Pleistocene of Kents Cavern, England, based on dental morphometrics." Historical Biology 23: 2-11.

This Article is brought to you for free and open access by the W.M. Keck Science Department at Scholarship @ Claremont. It has been accepted for inclusion in WM Keck Science Faculty Papers by an authorized administrator of Scholarship @ Claremont. For more information, please contact scholarship@cuc.claremont.edu. 
This article was downloaded by: [McFarlane, Donald]

On: 15 July 2010

Access details: Access Details: [subscription number 924434275]

Publisher Taylor \& Francis

Informa Ltd Registered in England and Wales Registered Number: 1072954 Registered office: Mortimer House, 3741 Mortimer Street, London W1T 3JH, UK

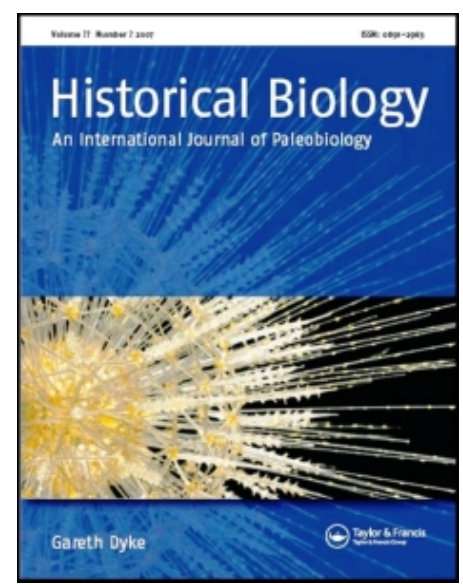

\section{Historical Biology}

Publication details, including instructions for authors and subscription information:

http://www.informaworld.com/smpp/title $\sim$ content=t713717695

\section{A unique population of cave bears (Carnivora: Ursidae) from the Middle} Pleistocene of Kents Cavern, England, based on dental morphometrics

Donald A. McFarlanea ; Martin Sabol'; Joyce Lundberg ${ }^{\mathrm{c}}$

a Joint Science Department, Scripps College, Claremont, CA, USA b Department of Geology and Palaeontology, Faculty of Sciences, Comenius University, Bratislava, Slovakia ${ }^{\mathrm{c}}$ Department of

Geography and Environmental Studies, Carleton University, Ottawa, Ont., Canada

First published on: 15 July 2010

To cite this Article McFarlane, Donald A., Sabol, Martin and Lundberg, Joyce(2010) 'A unique population of cave bears (Carnivora: Ursidae) from the Middle Pleistocene of Kents Cavern, England, based on dental morphometrics', Historical Biology,, First published on: 15 July 2010 (iFirst)

To link to this Article: DOI: $10.1080 / 08912963.2010 .483730$

URL: http://dx.doi.org/10.1080/08912963.2010.483730

\section{PLEASE SCROLL DOWN FOR ARTICLE}

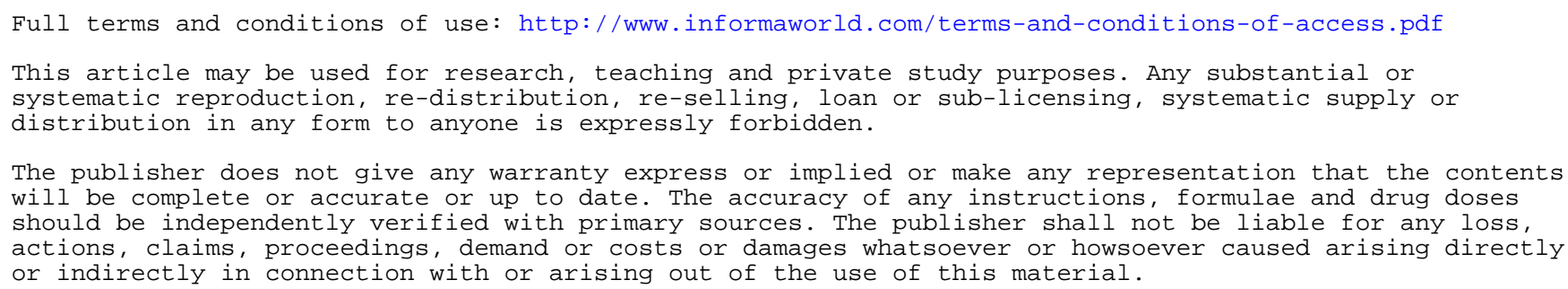




\title{
A unique population of cave bears (Carnivora: Ursidae) from the Middle Pleistocene of Kents Cavern, England, based on dental morphometrics
}

\author{
Donald A. McFarlane ${ }^{\mathrm{a} *}$, Martin Sabol ${ }^{\mathrm{b} \dagger}$ and Joyce Lundberg ${ }^{\mathrm{c} \ddagger}$ \\ ${ }^{a}$ Joint Science Department, Scripps College, 925 North Mills Avenue, Claremont, CA 91711, USA; ${ }^{b}$ Department of Geology and \\ Palaeontology, Faculty of Sciences, Comenius University, Mlynska dolina, SK-842 15 Bratislava, Slovakia; ${ }^{c}$ Department of Geography \\ and Environmental Studies, Carleton University, Ottawa, Ont., K1S 4B6, Canada
}

(Received 24 February 2010; final version received 5 April 2010)

\begin{abstract}
The 'breccia' stratum from Kents (we follow local tradition in using the form 'Kents', without an apostrophe) Cavern, England, has been well known for its rich yield of cave-bear material since excavations began in the mid-19th century. Recent work has established that the bears are of latest MIS 12 or earliest MIS 11 age. A life table based on a collection of 67 molariform teeth is consistent with the use of the cave as a hibernaculum. Univariate and morphological assessment of the teeth shows an unusual range of primitive and more derived characters. Multivariate morphometric analysis of cave-bear teeth from the site demonstrates that these animals, while currently assignable to Ursus deningeri sensu lato, are nevertheless morphologically distinct and not simply late deningeri on a hypothetical chronospecific continuum.
\end{abstract}

Keywords: Kents Cavern; Britain; cave; bear; Pleistocene; MIS 11

\section{Introduction}

Cave bears represent an exclusively European lineage of 'spelaeoid' ursids that appeared in the late Early to Middle Pleistocene following their separation from the brown bear (arctoid) line (Kurtén 1976). Traditional systematics posits that the earliest form is Ursus savini (Kurtén 1968), which graded into (or is considered to be an early variant of) U. deningeri (Mazza and Rustioni 1994). By the close of the Middle Pleistocene, the lineage was represented by $U$. spelaeus, which persisted until its final extinction in the latest Pleistocene. The evolution of this lineage was driven by increasing specialisation on herbivory (depending on local food sources), marked by a progressive doming of the skull, the loss of upper and lower anterior premolars and an increase in the occlusal area of the molars with suppression of the cusps. More recently, a flurry of molecular studies has benefitted from the abundant material and sometimes good preservation of Late Pleistocene cave-bear material, resulting in successful sequencing of ancient DNA and new insights into cave-bear systematics. On the basis of molecular clock estimates, the spelaeoid lineage is thought to have split from the arctoid lineage some 1.2 million years ago (Loreille et al. 2001). Spelaeoid bears have also been shown to be a genetically and morphologically diverse group, with four haplogroups currently recognised (Orlando et al. 2002). This diversity of form has led to differing views on systematics - Rabeder et al. (2004) and Knappe et al. (2009) consider spelaeoid bears of the Late Pleistocene to consist of at least two distinct species, $U$. spelaeus and $U$. ingressus, both derived from mid-Pleistocene $U$. deningeri, whereas Baryshnikov (2006) considers the post-deningeri bears to consist of a single, diverse species, $U$. spelaeus.

Bear fossils are relatively common in British caves (Yalden 1999), but these are generally later Pleistocene and Holocene brown bears. True 'cave' (spelaeoid) bears are known from relatively few British sites, probably all predating MIS 10 (Schreve 2001). Following the extirpation of the spelaeoid population by the MIS 10 glaciation of Britain, cave bears did not recolonise in the British Isles and were ecologically replaced by the brown bear, U. arctos, which persisted until the Roman era $\sim 2$ ka (Yalden 1999). The oldest British spelaeoid forms have been excavated from the open-air site at Bacton, the in-filled cave site of Westbury-sub-Mendip (Bishop 1982) and from Kents Cavern (Campbell and Sampson 1971; Proctor et al. 2005; Lundberg and McFarlane 2007), all deposits pre-dating the peak of the MIS 11 interglacial period. Cave bears have also been recovered from deposits of MIS 11 age or younger at Pontnewydd and Tornewton Caves (Gilmour et al. 2007). It is worth noting that any pre-MIS 11 bears would have been entirely extirpated by the ice-sheet advance of the MIS 12 (Anglian) glaciation; British spelaeoid bears from MIS 11 (and later, if any) must represent subsequent recolonisation from un-glaciated continental Europe.

\footnotetext{
†Email: sabol@fns.uniba.sk

†Email: joyce_lundberg.carleton.ca

ISSN 0891-2963 print/ISSN 1029-2381 online

(C) 2010 Taylor \& Francis

DOI: $10.1080 / 08912963.2010 .483730$

http://www.informaworld.com
}

*Corresponding author. Email: dmcfarlane@jsd.claremont.edu 
The Bacton bears have been regarded as $U$. savini, a lineage of uncertain relationship to other spelaeoid forms discussed here (Baryshnikov 2006). The Westburysub-Mendip bears are generally regarded as $U$. deningeri (Bishop 1982) and thought to be 'Cromerian' in age (a somewhat flexible term, now generally thought to be MIS 13 or earlier; Stringer 2006). The morphometric status of the Kents Cavern spelaeoid bears has never been critically reviewed, although Proctor et al. (2005) provide a comparison of mean tooth lengths without further statistical analysis. Here, we report the results of the first multivariate morphological analysis of cave-bear teeth from Kents Cavern, England (50.467 N: $3.503 \mathrm{~W}$ ) in comparison to those of continental European examples of unambiguous systematic assignment.

\section{Materials and methods}

The Kents Cavern sample consists of 67 bear molariform teeth collected from the 'Breccia' by William Pengelly, 1858-1880 (McFarlane and Lundberg 2005), and accessioned in the Torquay Museum. The sample includes $1 \mathrm{P} 4$ $\operatorname{dext}^{1}$., $1 \mathrm{M} 1$ dext., $6 \mathrm{M} 1 \sin ^{2}$., $11 \mathrm{M} 2$ dext., $16 \mathrm{M} 2$ sin., 1 p4 sin., $3 \mathrm{~m} 1$ dext., $3 \mathrm{~m} 1$ sin., $5 \mathrm{~m} 2$ dext., $11 \mathrm{~m} 2$ sin., $2 \mathrm{~m} 3$ dext. and $7 \mathrm{~m} 3 \mathrm{sin}$. The teeth belong minimally to 16 individuals ( $\mathrm{MNI}=16$, based on the number of left M2's).

Care must be taken with the Kents Cavern collection, because there is some potential for misidentification if isolated late Pleistocene brown bear teeth are mixed in collections with older spelaeoid teeth. We have used only molariform teeth unambiguously derived from the oldest fossil-bearing stratum in Kents Cavern, the 'Breccia' (Campbell and Sampson 1971; Proctor et al. 2005; Lundberg and McFarlane 2007).
All teeth were measured with calipers to a precision of $0.01 \mathrm{~mm}$ (standard deviation $0.03 \mathrm{~mm}$ or better) along standard axes (Stiner 1998). The multivariate dataset (10 variables, length and width of M1, M2, m1, m2 and m3) of U. deningeri, U. spelaeus and the Kents Cavern bears was projected into two dimensions using canonical variates analysis (CVA) following Hammer and Harper (2006) and implemented in PAST (http://folk.uio.no/oha mmer/past/). Similarly, discriminant function analysis (DFA) also following Hammer and Harper (2006) was used for pair-wise comparison of $U$. deningeri and $U$. spelaeus with the Kents Cavern specimens.

Finally, the teeth were aged according to wear stage (Stiner et al. 1998), and used to compute a standard static life table for the animals.

\section{Results}

Basic tooth measurements appear in Table 1.

\section{Morphology}

Tooth morphotypes are illustrated in Figure 1. From a morphological perspective, the P4 dext. is relatively primitive with the protocone situated on the lingual side of the tooth in a position between (or slightly posteriorly to) both the paracone and the metacone. This morphology is typical of early representatives of the deningerigroup. Additionally, the crown of the $p 4 \sin$. is relatively primitive, with only a paraconid and worn protoconid.

Most of MI's show rather arctos-like characters (the paracone is as large as the metacone, the anterior part of the crown is narrower and shorter than the posterior part, the protocone is undivided and the mesocone can be absent)

Table 1. Measurements of cave-bear teeth (in $\mathrm{mm}$ ) from the Kents Cavern, and number of specimens (in parentheses) of $U$. deningeri and $U$. spelaeus comparative material.

\begin{tabular}{|c|c|c|c|c|c|c|c|}
\hline \multicolumn{2}{|c|}{ Teeth } & \multirow{2}{*}{$\begin{array}{r}N \\
1\end{array}$} & \multirow{2}{*}{$\begin{array}{c}\text { Minimum } \\
-\end{array}$} & \multirow{2}{*}{$\frac{\text { Maximum }}{-}$} & \multirow{2}{*}{$\begin{array}{l}\text { Mean } \\
19.21\end{array}$} & \multirow[t]{2}{*}{ U. deningeri ${ }^{\mathrm{a}}$} & \multirow[t]{2}{*}{ U. spelaeus ${ }^{\mathrm{b}}$} \\
\hline$\overline{\mathrm{P} 4}$ & $\mathrm{~L}$ & & & & & & \\
\hline & W & 1 & - & - & 13.51 & & \\
\hline \multirow[t]{2}{*}{$\mathrm{p} 4$} & $\mathrm{~L}$ & 1 & - & - & 15.89 & & \\
\hline & W & 1 & - & - & 8.93 & & \\
\hline \multirow[t]{2}{*}{ M1 } & $\mathrm{L}$ & 7 & 24.19 & 30.62 & 26.34 & (5) & (16) \\
\hline & WA & 7 & 17.52 & 21.73 & 19.51 & (5) & (16) \\
\hline \multirow[t]{2}{*}{ M2 } & $\mathrm{L}$ & 27 & 35.99 & 49.95 & 43.05 & (4) & (24) \\
\hline & WA & 27 & 18.47 & 23.67 & 21.01 & (4) & (24) \\
\hline \multirow[t]{2}{*}{$\mathrm{m} 1$} & $\mathrm{~L}$ & 6 & 25.71 & 31.51 & 28.26 & (4) & (20) \\
\hline & TAW & 6 & 12.08 & 15.91 & 13.27 & (4) & (20) \\
\hline \multirow[t]{2}{*}{$\mathrm{m} 2$} & $\mathrm{~L}$ & 14 & 25.70 & 32.84 & 28.51 & (6) & (26) \\
\hline & TAW & 14 & 14.95 & 18.79 & 17.21 & (6) & (26) \\
\hline \multirow[t]{2}{*}{$\mathrm{m} 3$} & $\mathrm{~L}$ & 7 & 21.92 & 30.59 & 25.20 & (6) & (27) \\
\hline & WA & 7 & 15.85 & 20.90 & 17.67 & (6) & (27) \\
\hline
\end{tabular}

Notes: L, length; W, width; WA, anterior width; TAW, width of the talonid; P4, fourth upper premolar; p4, fourth lower premolar; M1, first upper molar; M2, second upper molar; $\mathrm{m} 1-\mathrm{m} 3$, first through third lower molars, respectively.

${ }^{a} U$. deningeri from Hundsheim (Musil 1957, 1960, 1972), Einhornhöhle, Urdhöhle, Stránska skála (Musil 1972), Bilzingsleben (Musil 1991), Chateau and Azé I-1 (Argant 1991).

${ }^{\mathrm{b}}$ U. spelaeus from 24 cave sites located in western, southern and central Europe (Paulus 1947; Musil 1956, 1959, 1962, 1965; Argant 1991; Paunović 1991; Sabol 2005). 


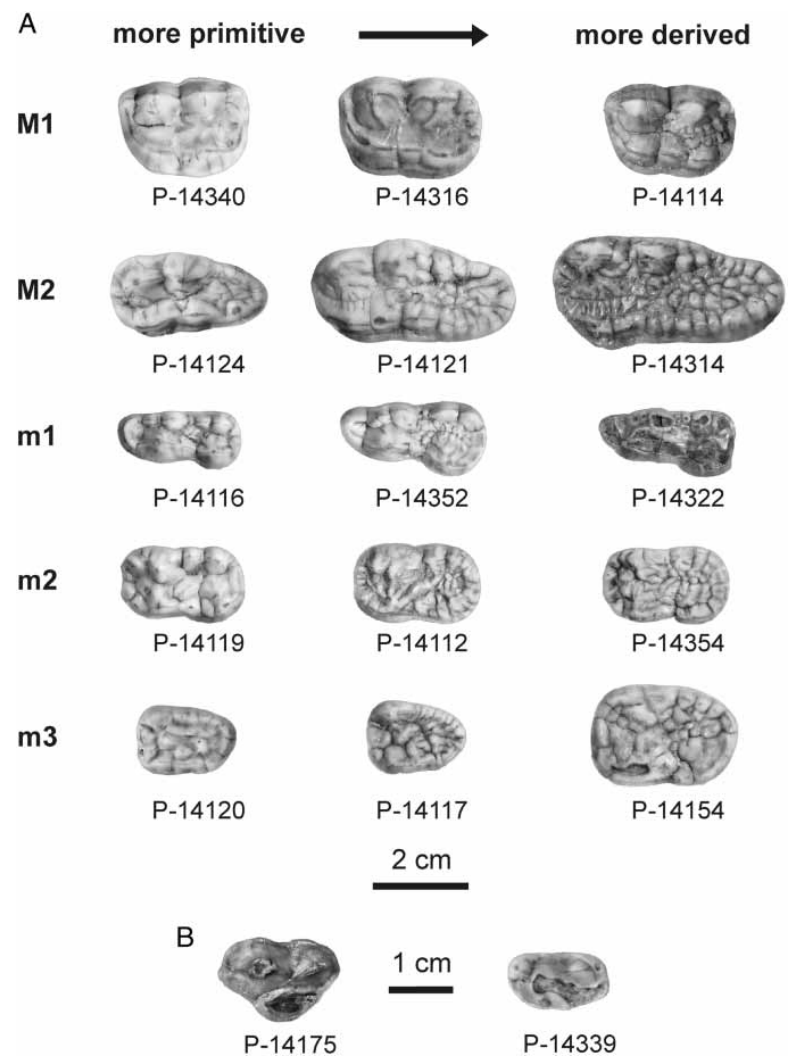

Figure 1. The occlusal view of the morphological types of teeth from Kents Cavern. A. Comparison of various molar 'morphotypes' from the site under study. B. Upper (P-14175) and lower (P-14339) fourth premolar. All teeth are figured as sinistral.

compared to the more derived characters seen in the teeth of bears from the spelaeus -group. In contrast, the large majority of the M2's can be regarded as 'early spelaeoid' and described as deningeri-like with characteristic divided protocone and an increased number of accessory cusps.

Although some of the Kents Cavern ml's under study display a more derived crown morphology (e.g. with a more divided metaconid complex and/or with an anterior entoconid cusp (End2) larger than posterior one (End1) resp.), close to the crown morphology of $U$. spelaeus molars, generally, the teeth are of a less derived form. A similar situation can be seen in $m 2$ ' $s$ with various stages of the metaconid complex development, mostly End1 larger than End2, a more derived hypoconid complex with divided enthypoconid, and with a relatively more derived morphology of the protoconid.

The last lower molars ( $\mathrm{m} 3$ 's) demonstrate a closer morphological relationship with this type of molar of $U$. spelaeus, having more complicated occlusal area in most of them.

\section{Univariate analysis}

Comparative samples of $U$. deningeri and $U$. spelaeus (Table 2) consist of molars because there are only single
Table 2. Life table for the Kents Cavern cave bears.

\begin{tabular}{lccccccc}
\hline $\begin{array}{l}\text { Wear stage } \\
\text { (age) }\end{array}$ & $n_{x}$ & $l_{x}$ & $d_{x}$ & $q_{x}$ & $L_{x}$ & $T_{x}$ & $e_{x}$ \\
\hline 1 & 68 & 1 & 0.01 & 0.01 & 0.99 & 3.31 & 3.3088 \\
2 & 67 & 0.99 & 0.19 & 0.19 & 0.89 & 2.32 & 2.3507 \\
3 & 54 & 0.79 & 0.34 & 0.43 & 0.63 & 1.43 & 1.7963 \\
4 & 31 & 0.46 & 0.22 & 0.48 & 0.35 & 0.80 & 1.7581 \\
5 & 16 & 0.24 & 0.09 & 0.38 & 0.19 & 0.46 & 1.9375 \\
6 & 10 & 0.15 & 0.04 & 0.30 & 0.13 & 0.26 & 1.8 \\
7 & 7 & 0.10 & 0.01 & 0.14 & 0.10 & 0.14 & 1.3571 \\
8 & 6 & 0.09 & 0.09 & 1.00 & 0.04 & 0.04 & 0.5 \\
\hline
\end{tabular}

Notes: $n_{x}$, number surviving to wear stage $x ; l_{x}$, proportion surviving to wear stage $x$; $d_{x}$, proportion dying in wear stage $x ; q_{x}$, age-specific mortality; $L_{x}$, proportion surviving to end of wear stage $x ; T_{x}$, proportionate wear stages remaining to individuals in wear stage $x$ and $e_{x}$, life expectancy in wear stages of an individual in wear stage $x$.

specimens of $P 4$ and $p 4$ in the Kents Cavern collection. For the univariate statistical analysis, mean values of U. deningeri molar teeth from Hundsheim (Musil 1957, 1960, 1972), Einhornhöhle, Urdhöhle, Stránska skála (Musil 1972), Bilzingsleben (Musil 1991), Chateau and Azé I-1 (Argant 1991) and mean values of $U$. spelaeus molar teeth from 24 cave sites located in western, southern and central Europe (Paulus 1947; Musil 1956, 1959, 1962, 1965; Argant 1991; Paunović 1991; Sabol 2005) have been used.

The range of measurements of the Kents cavern molars under study is large and generally exceeds and fully encompasses the range of deningeri bears (Figure 2); in contrast, the Kents Cavern data have a generally smaller range and are encompassed by the spelaeus data. There is also an interesting metric similarity to the teeth of small high-alpine forms of cave bears from both Ramesh (U. spelaeus eremus) and Conturines (U. spelaeus ladinicus) caves (Rabeder et al. 2004).

These metric data are confirmed by basic morphological analysis, which reveals a predominance of deningerilike molar characters (or 'early spelaeoid' ones), mixed with more plesiomorphic characters (arctos-like) or more derived, spelaeus-like ones (Figures 2 and 3).

\section{Multivariate analysis}

CVA reveals that $U$. deningeri and $U$. spelaeus project as consistent but overlapping entities (Figure 4), consistent with the widespread understanding that these are highly variable taxonomic units in the Late Pleistocene of continental Europe. Interestingly, the Kents Cavern specimens form a distinct and separate grouping.

DFA unambiguously separates the Kents Cavern bears from both $U$. spelaeus and U. deningeri (Figure 5A,B).

A two-group Mahalanobis permutation test also decisively separates the Kents Cavern bears from both $U$. deningeri (M-distance $1.949, p<0.0005)$ and $U$. spelaeus (M-distance 1.341, $p<0.0005$ ). 

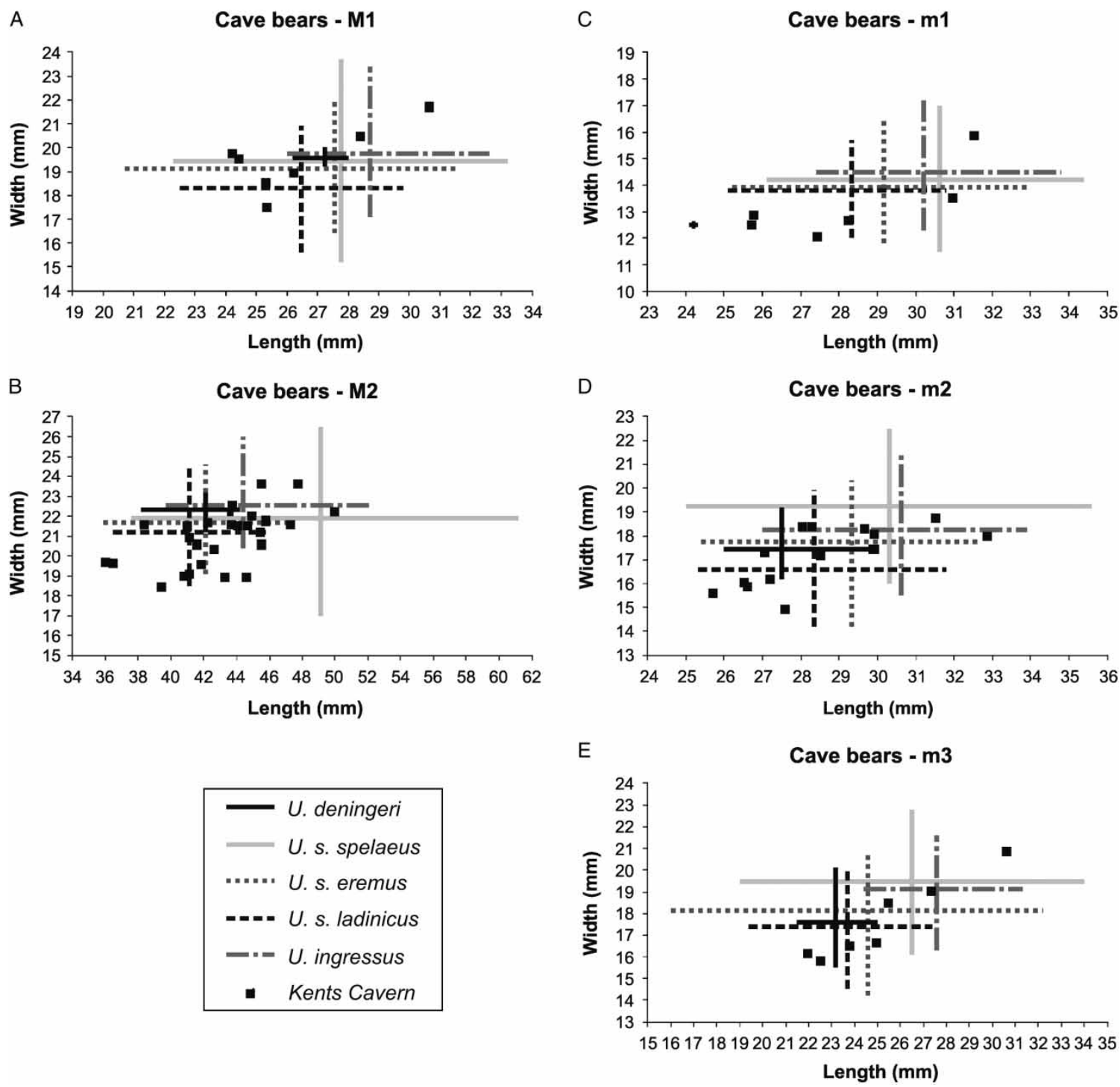

Figure 2. Scatter diagram comparing upper molars (M1-2; a, b) and lower molars (m1-3, c, d, e) of bears from Kents Cavern with ranges of upper molar measurements of $U$. deningeri from Mosbach (Reichenau 1904), high alpine cave-bear forms $U$. spelaeus eremus from Ramesch and U. spelaeus ladinicus from Conturines (Rabeder et al. 2004), U. ingressus from Gamssulzen (Rabeder et al. 2004), and U. spelaeus from continental Europe (Erdbrink 1953; Baryshnikov 2007).

\section{Life table}

All life (wear) stages are represented (Table 2 and Figure 6); juveniles (51\%) outnumber prime adults (40\%) and old adults (9\%) in the sample. The Type 1 survivorship curve is typical of extant large mammals with low predation risk.

\section{Discussion and conclusion}

The more plesiomorphic teeth are defined by their smaller dimensions and especially by their simplified crown morphology (e.g. an undivided protocone on upper molars or the absence of accessory cusps on lower molars), compared to the higher complexity of the occlusal surface of upper molars, and more developed metaconid and entoconid complexes ( $\mathrm{m} 1$ and $\mathrm{m} 2$ ) or enthypoconid complexes (m2) typical of the more derived condition.

Within the most numerous type of molars (M2), the 'early spelaeoid' stage dominates. A similar situation is repeated in the lower molars ( $\mathrm{m} 1$ and $\mathrm{m} 2)$, whereas the crowns of the third lower molars (m3) show a predominance of more derived characters. In contrast, the first upper molars have more primitive, plesiomorphic crowns (Figure 2).

On the basis of the morphological assessment and univariate molar data, the Kents Cavern Breccia bears can be assigned to Ursus deningeri sensu lato. The deningerilike form of P4 dext. and p4 sin. also supports this 


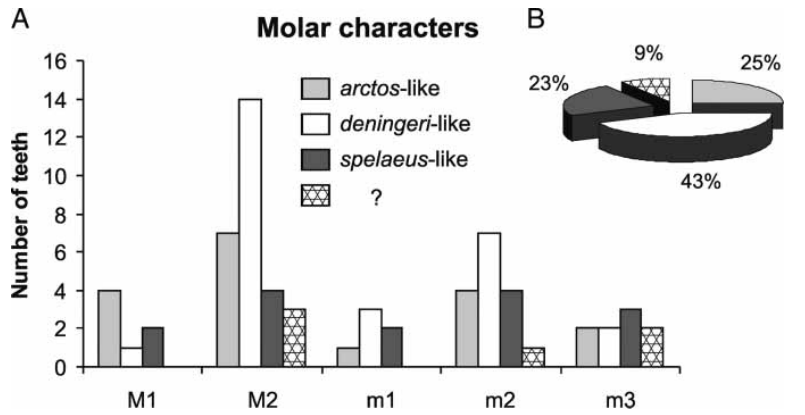

Figure 3. Statistical evaluation of bear molars from Kents Cavern. A. Division of bear molars based on the crown morphology. B. Percentage distribution of morphological characters on the molar crowns of bears under study. The question mark indicates a group of teeth without distinguishing crown morphologies.

determination, although it is not statistically demonstrable because of the small sample size. Multivariate analysis clearly demonstrates that the Kents Cavern bears were an isolated and unique population.

The Kents Cavern cave-bear life table, with all life stages represented in their expected proportions, is consistent with the use of the cave as a hibernaculum (Argenti and Mazza 2006). Although our sample is limited to the Torquay Museum material and does not represent the total recovery of bear teeth from the cave, the low MNI is instructive and consistent with plots of spatial distribution (Mihai et al. in press), which imply that the total number of bears represented was not high, and that the animals therefore were probably only using the cave for a relatively short period of time.

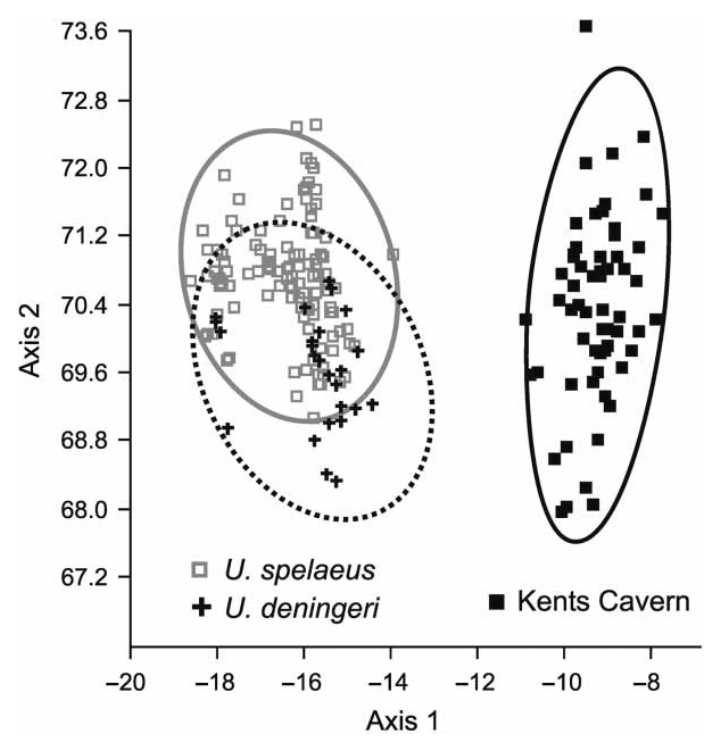

Figure 4. Canonical variate projection of cave-bear tooth measurements. Open squares, U. spelaeus; crosses, U. deningeri; filled squares, Kents Cavern.
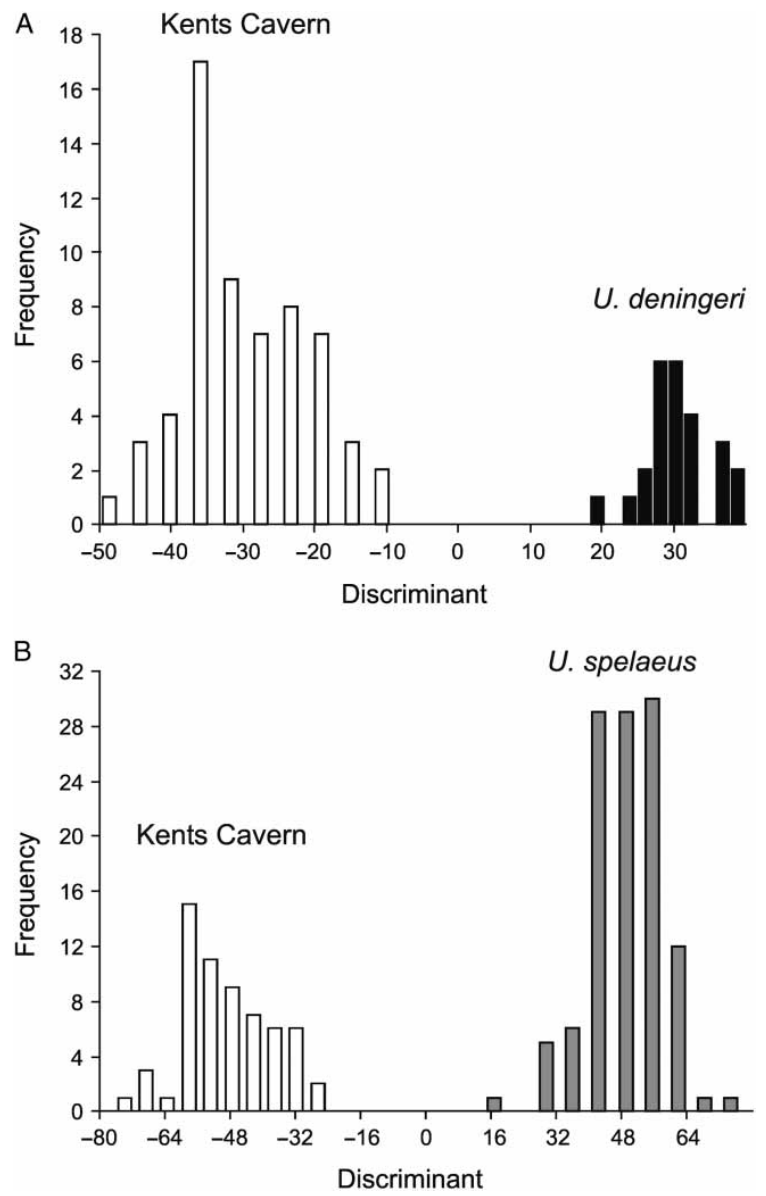

Figure 5. DFA of bear tooth measurements. A. Kents Cavern v. U. deningeri. B. Kents Cavern v. U. spelaeus. Significance of the discriminant function exceeds $10^{6}$ in both cases.

Proctor et al. (2005), in comparing the mean lengths of cave-bear teeth from Kents Cavern with specimens from Bacton, Westbury-sub-Mendip and continental Europe, note that the Kents Cavern bears are distinct from $U$. spelaeus, an observation which is not unexpected given that the Middle Pleistocene Kents Cavern form is being compared to post - MIS 11, predominantly Late Pleistocene, continental U. spelaeus. Proctor et al. (2005)

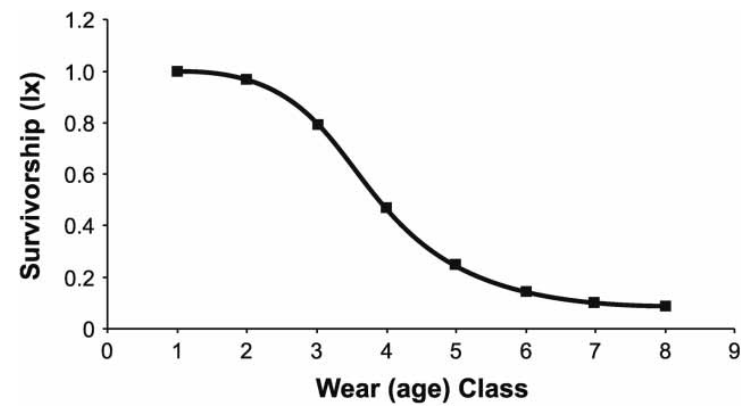

Figure 6. Survivorship curve, Kents Cavern cave bears. 
go on to note that the Kents Cavern bears 'compare well with $U$. deningeri from Westbury-sub-Mendip', at least with respect to the single parameter (molar length) analysed. As U. spelaeus and U. ingressus (alternatively, $U$. spelaeus ingressus) are considered, on mtDNA molecular clock evidence, to have diverged from the deningeri common ancestor 414-173 ka (Knappe et al. 2009), we can reasonably assign the MIS 12/early MIS 11 ( $\sim 400-450 \mathrm{ka}$ ) Kents Cavern cave bears to U. deningeri sensu lato for taxonomic purposes. However, our multivariate CVA suggests that the Kents Cavern deningeri-like bears are more distinctive than has previously been recognised, except perhaps with respect to their convergent similarity to Late Pleistocene dwarf forms from the Alps, noted by Kurtén (1976). This may reflect adaption to a relatively harsh late (MIS 12) glacial environment that may in turn mimic late Pleistocene high altitude Alpine environments. Morphologically, the specimens display a slight predominance of plesiomorphic characters over more derived spelaeus-like characters, especially in upper molars (Figure 3). Overall, however, the teeth show an 'early spelaeoid' morphology, which can be seen mainly in $\mathrm{M} 2, \mathrm{~m} 1$ and $\mathrm{m} 2$. From a metric perspective, most teeth considered individually fall within the range for $U$. deningeri. Generally, the whole sample can be judged 'deningeri-like', and provisionally assigned to Ursus ex gr. deningeri von Reichenau 1904, an assignment supported by the presence of primitive premolar morphotypes in the very few specimens available. Nevertheless, the multivariate data analysis clearly differentiates the Kents Cavern bears from 'classic' $U$. deningeri. Teasing apart the chronostratigraphic and biogeographic components of cave-bear morphological diversity remains a challenge, notwithstanding efforts by Baryshnikov (2006) and others, because very few cavebear fossils have been reliably dated beyond MIS 5 $(\sim 130 \mathrm{ka})$. Nevertheless, by analogy to recent work on the molecular systematics of Late Pleistocene continental European bears from the spelaeus-group (Orlando et al. 2002; Knappe et al. 2009), it would be prudent to assume that pre-MIS 10 cave-bear lineages may not be monophyletic (cf. Later Pleistocene alpine $U$. spelaeus populations, Hofreiter et al. 2002), reflecting limited gene flow even over relatively short geographic distances.

The biogeographic implications of the uniqueness of the Kents Cavern bears merit further consideration. Britain was contiguous with continental Europe during MIS13, but the chronology of its subsequent isolation has been the subject of considerable debate (c.f. Ashton and Lewis 2002). More recent evidence from an analysis of the paleoflood geomorphology of the English Channel (Gibbard 2007; Gupta et al. 2007) provides strong support for the rapid opening of the English Channel by the catastrophic draining of a proglacial lake that lay east of the present Straits of Dover. Although the timing of the first great
Channel megaflood has not been resolved precisely, Gibbard (2007) argues for an age of approximately 425,000 years BP, during late MIS12 time. The current best estimate of the age of the Kents Cavern bears is also late MIS 12 (Lundberg and McFarlane 2007). The implication is that the Kents bears derived from a group of $U$. deningeri that reached southern England late in MIS12, just prior to the Channel megaflood that first isolated Britain. If the colonising population was very small, and subsquent gene flow was impossible across the newly formed Channel, the morphological distinctness of the Kents Cavern bears is to be expected.

Given that it is very unlikely that molecular evidence will ever be recovered from British Middle Pleistocene bears, a rigorous, multivariate, morphological comparative analysis of the Westbury and Kents Cavern collections is probably warranted, and may justify a distinct taxonomic assignment for the British forms.

\section{Acknowledgements}

This research was supported by grants from Scripps College and the Grant Agency for Science, Slovakia (project APVV-028007). We thank Mr Barry Chandler of the Torquay Museum for access to specimens, and Mr Nick Powe of Kents Cavern for his encouragement of our studies.

\section{Notes}

1. dext. = dextral, i.e right side

2. $\sin .=$ sinistral, i.e. left side.

\section{References}

Argant A. 1991. Carnivores quaternaires de Bourgogne. Documentes des laboratoires de géologie Lyon. 115:1-301.

Argenti P, Mazza PPA. 2006. Mortality analysis of the Late Pleistocene bears from Grotta Lattia, central Italy. J Archaeol Sci. 33:1552-1558.

Ashton N, Lewis S. 2002. Deserted Britain: declining populations in the British Late Middle Pleistocene. Antiquity. 76:388-396.

Baryshnikov GF. 2006. Morphometric variability of cheek teeth in cave bears. Sci An Sch Geol. Aristotle Universirty of Thessaloniki. 98:81-102.

Baryshnikov GF. 2007. Fauna of Russia and neighbouring countries. Mammals, Vol. I. Issue 5, Ursidae. Nauka, Saint Petersburg, 544 p.

Bishop MJ. 1982. The mammal fauna of the early Middle Pleistocene cavern infill site of Westbury-sub-Mendip, Somerset. Spec Pap Palaeontol. 28:1-108.

Campbell JB, Sampson CG. 1971. A new analysis of Kents Cavern, Devonshire, England. Univ Oregon Anthropol Pap. 3:1-39.

Erdbrink DP. 1953. A review of fossil and recent bears of the old world I-II. Deventer: Min. Geologisch Instituut Rijsk Universiteit Utrecht. 598 p.

Gibbard P. 2007. Europe cut adrift. Nature. 448:259-260.

Gilmour M, Currant A, Jacobi R, Stringer C. 2007. Recent TIMS dating results from British Late Pleistocene vertebrate faunal localities: context and interpretation. J Quaternary Sci. 22(8):793-800.

Gupta S, Collier JS, Palmer-Felgate A, Potter G. 2007. Catastrophic flooding origin of shelf valley systems in the English Channle. Nature. 448:342-346.

Hammer O, Harper D. 2006. Paleontological data analysis. Oxford: Blackwell. $351 \mathrm{p}$.

Hofreiter M, Capelli C, Krings M, Waits L, Conard N, Münzel S, Rabeder G, Nagel D, Paunovic M, Jambrěsić G, et al. 2002. Ancient DNA 
analyses reveal high mitochondrial DNA sequence diversity and parallel morphological evolution of late Pleistocene cave bears. Mol Biol Evol. 19(8):1244-1250.

Knappe M, Rohland N, Weinstock J, Baryshnikov G, Sher A, Nagel D, Rabeder G, Pinhasi R, Schmidt HA, Hofreiter M. 2009. First DNA sequences from Asian cave bear fossils reveal deep divergences and complex phylogeographic patterns. Mol Ecol. 18:1225-1238.

Kurtén B. 1968. Pleistocene mammals of Europe. London: Weidenfeld \& Nicolson. 317 p.

Kurtén B. 1976. The cave bear story: life and death of a vanished animal. New York: Columbia University Press. 163 p.

Loreille O, Orlando L, Patou-Mathis M, Philippe M, Taberlet P, Hanni C. 2001. Ancient DNA analysis reveals divergence of the cave bear, Ursus spelaeus, and brown bear, Ursus arctos, lineages. Curr Biol. 11:200-203.

Lundberg J, McFarlane DA. 2007. Pleistocene depositional history in a periglacial terrane: a $500 \mathrm{ka}$ record from Kents Cavern, Devon, United Kingdom. Geosphere. 3:199-219.

Mazza P, Rustioni M. 1994. On the phylogeny of Eurasian bears. Palaeontogr Ant A. 230:1-38.

McFarlane DA, Lundberg J. 2005. The 19th century excavation of Kents Cavern, England. J Cave Karst Stud. 67:39-47.

Mihai S, Lundberg J, McFarlane DA, Chandler B. In press. The Pengellian legacy reconsidered: a GIS approach to spatial analysis of palaeontological and archaeological collections from Kents Cavern, England. P Geologist Assoc.

Musil R. 1956. Nové osteologické nálezy z jeskyně Axamitky. Anthropozoikum. 5:47-54.

Musil R. 1957. Osteologické nálezy zo šterkovny pod Stránskou skálou, čast 1. Anthropozoikum. 6:55-69.

Musil R. 1959. Jeskynní medvěd z jeskyně Barové. Časopis Moravského musea. Acta Musei Moraviae. 44:89-111.

Musil R. 1960. Paläontologische Funde in Sedimenten der Letzten Zwischneiszeit. Časopis Moravského musea. Acta Musei Moraviae. 45:99-136.

Musil R. 1962. Die Höhle, "Švédův stůl", ein typischer Höhlenhyänenhorst. Anthropos. 13(5):97-260.
Musil R. 1965. Die Bärenhöhle Pod hradem, Die Entwicklung der Höhlenbären im letzten Glacial. Anthropos. 18(10):7-92.

Musil R. 1972. Die Bären der Stránska skála. Anthropos. 20:107-112.

Musil R. 1991. Die Bären von Bilzingsleben. Bilzingsleben. 4:81-102.

Orlando L, Bonjean D, Bocherens H, Thenot A, Argant A, Otte M, Hanni C. 2002. Ancient DNA and population genetics of cave bears (Ursus speleaus) through space and time. Mol Biol Evol. 19:1920-1933.

Paulus M. 1947. Etudes sur la faune quaternaire de la vallee inferieure du Gard ou Gardon. Bull Du Museum d'Hist Nat de Marseille. $7(1): 1-77$.

Paunović M. 1991. Morphometrische und morphogenetische Untersuchungender Zähne des Ursus spelaeus Rosenm. et Heinroth aus der Höhle Veternica (NW Kroatien). RAD Hrvatske akademije znanosti i umjetnosti - Razred za prirodne znanosti. 458(25):1-19.

Proctor CJ, Berridge PJ, Bishop MJ, Richards DA, Smart PL. 2005. Age of Middle Pleistocene fauna and Lower Palaeolithic industries from Kent's Cavern, Devon. Quaternary Sci Rev. 24:1243-1252.

Rabeder G, Hofreiter M, Nagel D, Withalm G. 2004. New taxa of Alpine cave bears (Ursidae, Carnivora). Cahiers Scientifiques. 2:49-67.

Sabol M. 2005. Cave bears (Ursidae, Mammalia) from the Trojuholnik Cave (Slovakia). Mitt Komm Quartarforsch Osterr Akad Wiss. 14:161-175.

Schreve DC. 2001. Differentiation of the British late middle Pleistocene interglacials: the evidence from mammalian biostratigraphy. Quaternary Sci Rev. 20:1693-1705.

Stiner MC. 1998. Mortality analysis of Pleistocene bears and its paleoanthropological relevance. J Hum Evol. 34:303-326.

Stiner MC, Achyuthan H, Arsebuck G, Howell C, Josephson SC, Juell KE, Pigati J, Quade J. 1998. Reconstructing cave bear paleoecology from skeletons: a cross-disciplinary study of middle Pleistocene bears from Yarimburgaz Cave, Turkey. Paleobiology. 24(1):74-98.

Stringer C. 2006. Homo Britannicus. The incredible story of human life in Britain. London: Allen Lane. 319 p.

von Reichenau W. 1904. Ueber eine neue fossile Bären-Art Ursus deningeri mihi aus den fluviatilen Sanden von Mosbach. Jahrb d. nassau. Ver., 1 Nat. 57:1-11.

Yalden DW. 1999. The history of British mammals. London: Academic Press. $312 \mathrm{p}$. 